\title{
QUEM VAI POR AÍ AFLITO
}

\author{
por Ronaldo Correia de Brito
}

Escritor e médico

Acorda e tenta lembrar o sonho. Chegava ao Recife e encontrava a cidade em ruínas. Casas, ruas, calçamentos, jardins e árvores cobertos de líquen podre. Os amigos passam a caminho da morte, máscaras nos rostos, alguns em cadeiras de rodas com cilindros de oxigênio. Ninguém o reconhecia. Escutava uma cantiga semelhante à dos carregadores de piano. No passado eles enchiam as ruas de vozes alegres, enquanto carregavam o instrumento sobre as cabeças. Meu barco é veleiro... Pares de seis, oito ou dez homens, quase todos negros, os mais pobres descalços. As teclas amarradas dos pianos não percutiam o ritmo grave e cadenciado dos passos. ...das ondas do mar... Todos olhavam para ele sem vê-lo, portas e janelas fechadas. $\mathrm{O}$ esquecimento e a cegueira doem mais que o sono. Acordar não é de dentro, acordar é ter saída, os versos de João Cabral martelando o juízo.

Pula da cama. Tateia no escuro, afasta as cortinas de voil e os painéis do quarto, quase rasga o tecido fino. Abre a porta e sai até a varanda.

Setenta e cinco, conta os dias de isolamento.

Ainda não desmergulhou do sonho. O orvalho que sobrou da chuva assume a forma de corpos enfileirados, na contraluz dos postes. A rua deserta àquela hora da madrugada o assusta. Sem saber o que olhar primeiro, avista o bairro à sua frente.

Casa Forte. No passado, existiu um engenho e a casa-forte de Dona Anna Paes, casada com um nobre da corte do Príncipe 
Maurício de Nassau. Nessa hora, os escravos estariam moendo a cana de açúcar.

Os prédios cresceram em até mais de trinta andares, sementes plantadas na terra fértil. São muitos, esmagam as casas que resistem de pé, expulsam velhos moradores. A duras penas sobrevivem azulejos portugueses em fachadas, uma praça do paisagista Burle Max e alguns palacetes.

Não é a varanda do apartamento por onde mais gosta de contemplar o Recife, prefere o lado norte.

- Um abandono, resmunga como se a esposa o escutasse. Mas ela dorme noutro quarto, isolada com os sintomas da pandemia.

Menos mal, pensa e corre para a outra varanda, a que se debruça sobre Casa Amarela. Está nu, não se acanha de circular despido. A quem interessa o corpo de um velho, músculos e pele em frangalhos? Se pelo menos fosse o Michael Fassbender? Sente-se estranho apenas quando telefonam.

- Sim, sim, o exame confirmou. Mas ela não vai usar a cloroquina, nem antibióticos preventivos. Os médicos empurram remédios sem saber de nada. Ninguém sabe de nada, nem a Organização Mundial de Saúde. Dizem que a oms tem negócios com a indústria farmacêutica. E com o Bill Gates, também. Não duvido. Os laboratórios só pensam em faturar mais dinheiro.

O outro bairro, no lado oposto à varanda que buscou depois do sonho. Morros e alguns terrenos planos.

Gente de pele escura, barulho, mercado, feira.

O proprietário da casa distante das ruas centrais, num sítio que pertencia ao Engenho Monteiro, no final de linha do trem maxambomba, mandou pintá-la com argila ocre.

Amarela.

Assim nomeiam-se os lugares.

Quando primeiro ele viu os morros de Casa Amarela, a água corria de nascentes em meio a restos de mata atlântica. Agora são apenas lembranças. As casas de um andar cresceram para cima como zigurates, em dois, três, quatro andares. Malconstruídas, tombam com as barreiras nas chuvas fortes, soterrando famílias. 
Os terreiros das casas serviam ao culto dos orixás. Perseguidas, as religiões de matriz africana foram empurradas para longe, calaram as vozes e os instrumentos de toque, arrancaram os santos do altar das divindades e deixaram-se engolir pelas religiões dos brancos, assimiladas por catequese. Em cada esquina ou a cada cem metros ergue-se um templo evangélico. Pentecostais e neopentecostais munem-se de bíblias e crença na ascensão social.

Deixam dez por cento de dízimo nas mãos do pastor. E cantam gospels nos cultos de domingo. Seria delírio imaginá-los cantando nesta madrugada, quando cocoricam os galos. Num mosteiro católico, na aurora após as matinas, talvez ainda se entoem salmos e cânticos de louvor a Deus. Mas não há mosteiros nem conventos nas proximidades.

Algumas cores se insinuam nas fachadas das residências: azuis, rosas, amarelas. Predominam as paredes de tijolo sem revestimento nem pintura, os telhados de amianto. Lonas pretas de plástico cobrem as barreiras, tentam impedir que desmoronem. Há lixo nas encostas, arbustos e poucas fruteiras. $\mathrm{O}$ sol nascente rarefaz a neblina espessa, deixa ver nuvens volumosas, como nos quadros de Eckhout. Um óleo retrata a índia pelada, o sexo coberto por folhas. Ela segura um antebraço humano e a mão decepados. Num cesto às costas, uma perna com um pé. A pintura impressionava europeus calvinistas pela nudez e alusão ao canibalismo. $O$ céu de pinceladas escuras e o cenário ordenado como natureza morta revelam um trópico artificial. Eckhout não pesquisou se os índios comiam carne humana fora de rituais canibalescos, nem se carregavam pedaços de corpos em cestos de coleta, como se viessem de um açougue ou supermercado.

Irrita-se, cansou de colonialismo e interpretações falsas da cultura. Grita sem importar-se com a hora cedo. Agita as mãos enfurecido, imagina os inimigos à sua frente, perfilados, prontos para o combate. Os índios e os negros faziam assim, antes de se atracarem com lanças, porretes e tacapes.

- E se eu me pintar de vermelho e sair pelado para a rua? pergunta-se. Posso alegar minha genética.

Falsidade ideológica.

É branco como quase todos os ricos do bairro da Casa Forte de Dona Anna Paes, tem os olhos azuis e o cabelo claro, descende 
de famílias sem mistura. Isso é possível no Brasil? Não. Sabe que nasceu sem a mancha mongólica nas nádegas, a que indica mestiçagem. A avó paterna, quando os netos chegavam ao mundo, vinha conferir se acontecera alguma mistura de sangue. Acendia uma lâmpada, punha os óculos, corria os dedos magros sobre a pele branca e rosada dos inocentes.

Inclina-se para os morros de Casa Amarela, mesmo sendo um branco da casa grande. Os antepassados sentiam atração pela senzala.

Sem reagir, aceitou a prisão domiciliar proclamada por homens de ciência e políticos. Mas afirma que a Ciência não sabe de nada, sofreu um crash igual ao da bolsa de valores de Nova York. Regressou ao mito, ao tempo em que se explicava o eco das grutas como a existência de uma ninfa Eco, condenada a repetir as últimas palavras porque recusara o amor de Pan.

Ciência - Não sei de nada!

Eco - Nada, nada, nada, nada...!

$\mathrm{Na}$ ausência de conhecimentos sobre o vírus e os transtornos causados por ele, enchem os pacientes de drogas. Até políticos prescrevem remédios, como se fossem infectologistas ou biólogos.

Cloroquina.

A quarentena se tornou a única medieval certeza. Em nome dela, filhos se separam dos pais, irmãos de irmãos, avôs de netos, namorados de namoradas, amigos de amigos. Famílias são fragmentadas, casamentos adiados, encontros postergados. Movimentos, passeatas, protestos públicos, tudo o que representa comunhão de ideias e luta se desfaz na ausência de convívio. Proíbem-se ajuntamentos, mobilizações. Eleições adiadas. Para quando? Quem está no poder permanece no poder, garantido pela manipulação do medo de contágio e da morte. O terror da Inquisição, da fogueira, de ser condenado ao inferno. Ficamos sós, brada. A individuação foi proscrita, berra. Pratica-se o individualismo camuflado em coletividade, grita e desfere pontapés nas paredes.

Decide romper a quarentena. Se não ganhar as ruas, enlouquece. A esposa gemendo com dor e febre. Não pensa nela.

Não acatará mais o exílio, enquanto os morros povoados de casas e gente se iluminam ao sol passageiro. 
Veste bermuda e camiseta, calça o tênis, despreza a máscara e as luvas, passa sorrateiro pelo corredor e vê a esposa no sono agitado da febre. Sofre um recuo na vontade, sente culpa.

Desce à garagem, cumprimenta o porteiro, transpõe o portão do edifício e sai para a rua. Caminhar sozinho aterroriza, estranha os passos e o silêncio incomum. Pensa em retornar, talvez chore.

Não sou chinês, nem confucionista, nem taoísta, afirma com raiva. Leu na sabedoria do Tao que somente quando estivermos fartos de nossa doença, poderemos parar de ser doentes. E por que esta obediência sem rebeldia? A quem interessa sua prisão? A que poder totalitário deve sacrificar a liberdade? Os chineses que o façam, sem questionar as ordens vindas de cima.

Atravessa ruas de Casa Forte, chega ao Poço da Panela, onde as pessoas vinham banhar-se durante as epidemias, na esperança de cura milagrosa. Desejando que as águas de uma nascente não se perdessem, os antigos moradores do lugar revestiram as paredes do poço com barro, no formato de uma panela.

Onde leu essas coisas? Para que enche a cabeça de conhecimentos inúteis? Aproxima-se da igreja de Nossa Senhora da Saúde, do século XVIII. Ao lado, um busto de José Mariano, o abolicionista, erguido sobre o corpo de um negro sem identidade. A residência acanhada onde morou José Mariano contrasta com os casarões antigos de pessoas ricas, que procuravam as águas salubres e limpas do rio.

Quem vai por aí aflito, místico, nu?

Deseja responder a pergunta de Whitman.

Resolve banhar-se.

Se aproxima do Capibaribe, o rio entulhado de sujeira e esgotos, coberto pelas plantas baronesas da poluição. Despe a roupa e se descalça. $\mathrm{O}$ corpo arruinou-se em três meses sem academia e caminhadas. Joga-se na água fria, aspira o mau cheiro. Tenta firmar os pés.

Lembra um resto de poesia: que os meses sejam de vácuo e o chão seja de lama e podridão. 茂 